\title{
Glosa do postanowienia Sądu Najwyższego z dnia 27 listopada 2014 r., sygn. IV CSK 115/14
}

Teza: „Brak jakichkolwiek podstaw, aby sprawy związane z zatrzymaniem przez zamawiającego wadium wyłączyć spod regulacji ustawy Prawo zamówień publicznych. Wobec tego zgodnie $\mathrm{z}$ art. 198a [...] [p.z.p. - dop. K.R.] dopiero po wydaniu orzeczenia przez Krajową Izbę Odwoławcza, powstaje właściwość sądu powszechnego".

\section{Wprowadzenie}

Glosowane orzeczenie porusza istotny problem dogmatyczny kognicji Krajowej Izby Odwoławczej (KIO, Izba) i sądów powszechnych w sprawach o zwrot wadium zatrzymanego przez zamawiającego, a konkretyzując - o zasądzenie jego wartości. Podjęcie polemiki z przemyśleniami wyrażonymi przez Sąd Najwyższy w postanowieniu z 27 listopada 2014 r. uzasadnione jest nie tylko ważkością problematyki zarówno dla praktyki, jak i nauki prawa zamówień publicznych, ale również brakiem wypracowania przez SN w tym zakresie jednolitej linii orzeczniczej. W zbieżnym stanie faktycznym 12 lutego 2014 r. SN wydał odmienne postanowienie ${ }^{2}$,

${ }^{1}$ Postanowienie Sądu Najwyższego (SN) z 27 XI 2014 r., sygn. IV CSK 115/14, LEX nr 1650297.

2 Postanowienie SN z 12 II 2014 r., sygn. IV CSK 291/13, LEX nr 1441196. 
które było przedmiotem dwóch glos ${ }^{3}$. Rozbieżność poglądów nie stanowi jedynego argumentu przemawiającego za koniecznością poddania ocenie stanowiska SN wyrażonego w głosowanym orzeczeniu. Zdaniem autora oba orzeczenia, jak i przywołane glosy, nie w pełni uwzględniają meritum problemu, co może skutkować występowaniem w przyszłości kolejnych problemów interpretacyjnych. Zważając na niezwykłą lapidarność uzasadnienia postanowienia SN z 27 listopada 2014 r., a także pobieżność argumentacji SN, niezbędne jest usystematyzowanie tejże materii i spojrzenie na nią przez pryzmat przyjętej w ramach prawa zamówień publicznych ${ }^{4}$ konstrukcji środków ochrony prawnej.

Na wstępie należy zauważyć, że przepisy wchodzące w życie na skutek nowelizacji ustawy p.z.p. ${ }^{5} \mathrm{w}$ okresie, którego ramy $\mathrm{z}$ jednej strony wyznacza moment badania sprawy przez sąd I instancji, a z drugiej przygotowanie niniejszej glosy, odmiennie regulują niektóre kwestie związane $\mathrm{z}$ instytucją wadium. W przyjętym $\mathrm{w}$ glosie za postanowieniem SN zakresie problematyki stan prawny pozostał niezmieniony.

\section{Stan faktyczny}

Zawisła przed SN sprawa dotyczyła postępowania o udzielenie zamówienia publicznego regulowanego przepisami p.z.p., w którym uczestnictwo warunkowane było m.in. wniesieniem wadium. Tenże instrument prawny zabezpieczać ma interes zamawiającego $\mathrm{w}$ trakcie postępowania o udzielenie zamówienia. W przywołanym stanie faktycznym, pomimo zakończenia postępowania, instytucja zamawiająca nie zwróciła wykonawcy wniesionego wadium, co stało się podstawą skierowania sprawy na drogę postępowania sądowego.

Sąd I instancji, uznając, że powód przed skierowaniem sprawy na drogę sądową powinien złożyć odwołanie do KIO, postanowieniem odrzucił pozew o zapłatę. Z kolei sąd II instancji postanowieniem oddalił zażalenie na postanowienie o odrzuceniu pozwu.

3 J. May, Glosa do postanowienia SN z 12.2.2014 r., IV CSK 291/13, „Prawo Zamówień Publicznych" 2014, nr 4, s. 93-100; M. Sieradzka, Glosa do postanowienia SN z dnia 12 lutego 2014 r., IV CSK 291/13, LEX nr 240047.

4 Ustawa z dnia 29 I 2004 r. Prawo zamówień publicznych (tekst jedn. Dz.U. 2015, poz. 2164), dalej „p.z.p.”.

5 Ustawa z dnia 29 VIII 2014 r. o zmianie ustawy - Prawo zamówień publicznych (Dz.U. 2014, poz. 1232). 
Sąd Najwyższy postanowieniem z 27 listopada 2014 r. oddalił skargę kasacyjna, wskazując w uzasadnieniu orzeczenia, że „brak jakichkolwiek podstaw, aby sprawy związane $\mathrm{z}$ zatrzymaniem przez zamawiającego wadium wyłączyć spod regulacji ustawy Prawo zamówień publicznych. Wobec tego zgodnie $z$ art. 198a p.z.p. dopiero po wydaniu orzeczenia przez Krajową Izbę Odwoławczą powstaje właściwość sądu powszechnego".

\section{Określenie problemu}

Szczegółowym problemem wynikającym z przywołanego orzeczenia jest właściwość orzecznicza KIO oraz sądów powszechnych w sprawach o zwrot wadium wniesionego w celu spełnienia warunku uczestniczenia w postępowaniu o udzielenie zamówienia publicznego. Zakotwiczony jest on w szerszych trudnościach związanych z zaklasyfikowaniem prawa zamówień publicznych do jednej z tradycyjnie wyróżnianych gałęzi prawa, jednoznaczną oceną statusu organizacyjno-prawnego $\mathrm{KIO}$, a także charakterem postępowania odwoławczego toczącego się przed tym podmiotem orzeczniczym.

\section{Charakter postępowania odwoławczego}

Zgodnie z art. 1 p.z.p. „ustawa określa zasady i tryb udzielania zamówień publicznych, środki ochrony prawnej, kontrolę udzielania zamówień publicznych oraz organy właściwe w sprawach uregulowanych w ustawie". Zatem ustawodawca w p.z.p. uregulował wiele kwestii związanych nie tylko z przygotowywaniem oraz udzielaniem zamówień publicznych, ale również z kontrolą sprawowaną przez prezesa Urzędu Zamówień Publicznych i KIO oraz zakresem zadań i kompetencji tychże organów.

KIO w przyjętym przez ustawodawcę kształcie należy do instytucji, które nie mają jednoznacznie zdefiniowanej pozycji prawnoustrojowej. Próby jej określenia były dokonywane w doktrynie co najmniej kilkukrotnie $^{6}$. Na potrzeby czynionych rozważań za wystarczające należy

${ }^{6}$ K. Solecka, Pozycja prawnoustrojowa Krajowej Izby Odwoławczej, w: Kontrola zamówień publicznych. Materialy pokonferencyjne VI Konferencji naukowej UZP, pod red. T. Kocowskiego, J. Sadowego, Wrocław-Warszawa 2013, s. 199-205; J. Niczyporuk, Krajowa Izba Odwoławcza-organ administracji regulacyjnej, w: Nowe podejście do zamówień publicznych-zamówienia 
uznać stwierdzenie, że KIO jest samodzielnym, kolegialnym organem administracji publicznej szczególnego hybrydowego rodzaju, spełniającym określone prawem funkcje jurysdykcyjne w zakresie wyspecjalizowanej dziedziny prawa, jaką stanowią zamówienia publiczne ${ }^{7}$.

Ustawodawca powołał KIO w celu kontrolowania przez nią zachowań zamawiających z uwzględnieniem kryterium legalności. Organ ten podejmuje działania kontrolne wyłącznie na wniosek ${ }^{8}$ uprawnionego podmiotu (art. 179 p.z.p.), w sytuacji zaistnienia sporu co do zgodności działań instytucji zamawiającej z ustawowo określonym wzorem postępowania.

Zakres sporów poddanych kognicji KIO został określony w art. 180 ust. 1 p.z.p., zgodnie z którym „odwołanie przysługuje wyłącznie od niezgodnej z przepisami ustawy czynności zamawiającego podjętej w postępowaniu o udzielenie zamówienia lub zaniechania czynności, do której zamawiający jest zobowiązany na podstawie ustawy". A contrario przedmiotem zarzutów odwołania nie może być np. zachowanie innych podmiotów niż gospodarz postępowania. Dodatkowo ustawodawca dookreślił ramy, w których nastąpić musi zachowanie zamawiającego, by mogło być ono przedmiotem kontroli KIO. Czynności lub zaniechania instytucji zamawiającej muszą zostać podjęte $w$ ramach postępowania o udzielenie zamówienia. Prima facie zdawać by się mogło, że postępowanie to rozpoczyna się podjęciem decyzji o konieczności nabycia określonych towarów lub dóbr, a kończy zawarciem umowy w sprawie zamówienia publicznego. Jednakże w świetle regulacji p.z.p. jest ono wyłącznie jednym z etapów procesu udzielania zamówienia. Zgodnie $z$ art. 2 pkt 7a p.z.p. postępowaniem o udzielenie zamówienia jest „postępowanie wszczynane w drodze publicznego ogłoszenia o zamówieniu lub przesłania zaproszenia do składania ofert albo przesłania zaproszenia do negocjacji w celu dokonania wyboru oferty wykonawcy, z którym zostanie zawarta umowa w sprawie zamówienia publicznego, lub - w przypadku trybu zamówienia $\mathrm{z}$ wolnej ręki - wynegocjowania postanowień takiej umowy".

publiczne jako instrument zwiększania innowacyjności gospodarki i zrównoważonego rozwoju. Doświadczenia polskie i zagraniczne. Materiały pokonferencyjne IV Konferencji naukowej UZP, pod red. T. Kocowskiego, J. Sadowego, M. Urbanka, Kazimierz Dolny 2011, s. 105-110; A. Panasiuk, Pozycja ustrojowa Krajowej Izby Odwoławczej, w: System zamówień publicznych. Zarys wykładu, Warszawa 2013, s. 199-205.

7 Zob. K. Różowicz, Charakterystyka środków ochrony prawnej przewidzianej przepisami ustawy Prawo zamówień publicznych, "Studia Prawa Publicznego” 2014, nr 4, s. 131-137.

8 Zgodnie z przepisami Rozdziału 2 Działu VI p.z.p. jest nim odwołanie. 
Uzupełniająco należy się zastanowić, jaki rodzaj orzeczenia powinna wydać KIO, jeżeli przedmiotem odwołania będzie czynność/ zaniechanie instytucji zamawiającej na etapie innym niż postępowanie o udzielenie zamówienia, np. na expressis verbis wyróżnionym przez ustawodawcę etapie przygotowawczym (Rozdział 2 Dział II p.z.p.).

Katalog wydawanych przez KIO orzeczeń obejmuje m.in.: postanowienie o zwrocie odwołania (art. 187 ust. 6 p.z.p.), postanowienie o odrzuceniu odwołania (art. 189 ust. 2 p.z.p.), postanowienie o umorzeniu postępowania odwoławczego (art. 186 ust. 2, 3 i 4 p.z.p. oraz art. 187 ust. 8 p.z.p.), wyrok oddalający odwołanie albo uwzględniający odwołanie (art. 192 ust. 1 p.z.p.).

Dokonując analizy przesłanek wydania poszczególnych rodzajów orzeczeń, należy wskazać, że żadna z nich wprost nie odnosi się do wąsko sprecyzowanej okoliczności wniesienia odwołania na czynność lub zaniechanie, podjęte przez zamawiającego na innym etapie niż postępowanie o udzielenie zamówienia.

Wśród przesłanek obligujących KIO do wydania postanowienia o odrzuceniu odwołania (verba legis: Izba odrzuca odwołanie) ustawodawca przewidział: brak zastosowania w sprawie przepisów ustawy (verba legis: w sprawie nie mają zastosowania przepisy ustawy, art. 189 ust. 2 pkt 1 p.z.p.). Pomimo pewnej dozy enigmatyczności przywołanej przesłanki należy $\mathrm{w}$ pełni zgodzić się $\mathrm{z}$ poglądem wyrażonym przez J. Jerzykowskiego, że „odwołanie podlega odrzuceniu także wówczas, gdy do danego postępowania o udzielenie zamówienia publicznego nie stosuje się przepisów o odwołaniach" ${ }^{\prime \prime}$. Ergo odwołanie, którego przedmiotem jest zachowanie zamawiającego na innym etapie niż postępowanie o udzielenie zamówienia, podlega odrzuceniu w drodze postanowienia.

Jednakże w sytuacjach bardziej złożonych, np. gdy przedmiotem odwołania będzie zarówno zachowanie zamawiającego na etapie postępowania o udzielenie zamówienia, jak i poza nim, wobec braku możliwości wydania przez KIO orzeczenia częściowego (w tym również postanowienia o odrzuceniu odwołania w części), zgodnie $z$ utrwalonym przez KIO zwyczajem, organ ten "rozpoznaje odwołanie, z tym że zarzuty, co do których zachodzą okoliczności wymienione w art. 189 ust. 2 ustawy p.z.p., oddala się, bez merytorycznego

9 J. Jerzykowski, Komentarz do art. 189 ustawy - Prawo zamówień publicznych, w: W. Dzierżanowski, J. Jerzykowski, M. Stachowiak, Prawo zamówień publicznych. Komentarz, LEX nr 433061. 
ich rozpoznania"10. Praktyka ta nie znajduje wyraźnego umocowania w przepisach prawa, ma wyłącznie uzasadnienie pragmatyczne. Zatem KIO wyda postanowienie o odrzuceniu odwołania wyłącznie w sytuacji, gdy żaden z podnoszonych przez odwołującego zarzutów nie może być rozpoznany z powodów określonych w art. 189 ust. 2 ustawy p.z.p.

\section{Termin zwrotu wadium}

W uzasadnieniu faktycznym glosowanego orzeczenia przywołano pogląd sądu II instancji, który uznał, że "wniesienie wadium stanowi element postępowania o udzielenie zamówienia publicznego, albowiem umożliwia branie udziału w takim postępowaniu, stanowi więc instytucję właściwą dla postępowania o udzielenie zamówienia publicznego". Zważając na charakter prawny instytucji wadium, a także na sposób ukształtowania procesu udzielania zamówień, niewątpliwie należy podzielić tenże pogląd. Nie sposób jednak uznać, że czynność wnoszenia wadium jest czynnością tożsamą z jej zwrotem.

Nie sposób również zgodzić się z poglądem wyrażonym przez KIO, na który powołał się sąd II instancji, a za nim SN, że "decyzja zamawiającego dotycząca zatrzymania wadium jest decyzją w postępowaniu o udzielenie zamówienia publicznego i co do jej zasadności podlega ocenie izby" ${ }^{\prime 11}$. Ustawodawca nie określił explicite, w którym momencie decyzja ta ma zostać podjęta. Zważając jednak na treść przesłanek pozwalających na zatrzymanie wadium oraz ich uzależnienie od zachowań wykonawców w trakcie postępowania o udzielenie zamówienia, prawidłowo podjęta decyzja, a więc zgodna z prawem, może nastąpić zarówno w trakcie postępowania o udzielenie zamówienia, jak i po tym etapie. Zatem za w pełni zgodne $\mathrm{z}$ regulacjami p.z.p. należy uznać podjęcie jej na etapie postępowania o udzielenie zamówienia, jak i po wyborze oferty najkorzystniejszej. Decyzja o zatrzymaniu wadium skorelowana jest $\mathrm{z}$ zachowaniem wykonawcy $\mathrm{w}$ ramach postępowania o udzielenie zamówienia, nie jest jednak z nim tożsama. Nie należy jej również utożsamiać z zachowaniem zamawiającego, np. wykluczeniem wykonawcy z postępowania, pomimo że gospodarz postępowania podejmuje decy-

\footnotetext{
10 Wyrok KIO z 30 III 2012 r., sygn. KIO 482/12, LEX nr 1131254.

11 Wyrok KIO z 27 IX 2010 r., sygn. KIO 1990/10, LexPolonica nr 2403573.
} 
zję o zatrzymaniu wadium z uwzględnieniem tejże okoliczności. Należy również zauważyć, że decyzja ta, pomimo że niezgodnie z prawem, może być podjęta przez zamawiającego w sposób uprzedni, jeszcze przed rozpoczęciem procesu nabywania dóbr lub usług.

Powyższe skutkuje tym, że ustawodawca expressis verbis określił moment, w którym zamawiający zwraca wadium. Od tego momentu liczone są terminy na skorzystanie ze środków ochrony prawnej. Materię tę w odniesieniu do trybu przetargu nieograniczonego reguluje art. 46 p.z.p. Odesłanie do tego przepisu zawierają: art. 53 p.z.p. (przetarg ograniczony), art. 60 p.z.p. (negocjacje z ogłoszeniem), art. 60e p.z.p. (dialog konkurencyjny), art. 64 p.z.p. (negocjacje bez ogłoszenia), art. 76 p.z.p. (licytacja elektroniczna), art. 101 p.z.p. (umowa ramowa) oraz art. 105 p.z.p. (dynamiczny system zakupów).

Ustawodawca nie określił jednego momentu, w którym nastąpić ma zwrot wadium. Najwcześniej zamawiający zobowiązany jest do jego zwrotu wykonawcy, który wycofał ofertę, przed upływem terminu składania ofert (art. 46 ust. 2 p.z.p.). Wykonawca ten musi złożyć wniosek o zwrot wadium. W ustawie nie zostało przesądzone, jak zamawiający powinien postąpić w przypadku niezłożenia przez wykonawcę wniosku. Zważając na zasadę równego traktowania wykonawców (art. 7 ust. 1 p.z.p.), zasadne zdaje się w tym wypadku odwołanie do reguły ogólnej, zgodnie z którą zamawiający zwraca wadium po wyborze oferty najkorzystniejszej albo po unieważnieniu postępowania.

Pozostałym wykonawcom, z wyjątkiem tego, którego oferta została wybrana jako najkorzystniejsza, zamawiający zwraca wadium niezwłocznie po zakończeniu postępowania o udzielenie zamówienia. Należy jednocześnie zauważyć, że zamawiający zwróci wadium, jeżeli nie będzie zobowiązany do jego zatrzymania (art. 46 ust. 4 a i 5 p.z.p.).

Wykonawcy, którego oferta została wybrana jako najkorzystniejsza, zamawiający zwraca wadium niezwłocznie po zawarciu umowy w sprawie zamówienia publicznego oraz wniesieniu zabezpieczenia należytego wykonania umowy, jeżeli jego wniesienia żądano (art. 46 ust. 1a). W tym samym momencie, a więc po zawarciu umowy oraz wniesieniu zabezpieczenia należytego wykonania umowy, zamawiający zwróci wadium wykonawcy, którego oferta została wybrana jako najkorzystniejsza w wyniku wydania rozstrzygnięcia przez KIO. Takiemu wykonawcy zostanie zwrócone ponownie wniesione wadium (art. 46 ust. 3 p.z.p.). 


\section{Konsekwencje procesowe niejednolicie określonego momentu zwrotu wadium}

Niejednolite ukształtowanie terminu zwrotu wadium wpływa na sytuację procesową wykonawców. Należy zauważyć, że zasadniczo zwrot wadium następuje po wybraniu oferty najkorzystniejszej albo unieważnieniu postępowania. Powyższe bezpośrednio przesądził ustawodawca $\mathrm{w}$ art. 46 p.z.p. Jedynie w przypadku gdy zwrot wadium następuje na rzecz wykonawcy, który wycofał ofertę przed upływem terminu składania ofert oraz złożył odpowiedni wniosek, zamawiający dokonuje tej czynność na etapie postępowania o udzielenie zamówienia.

Zatem zasadniczo KIO zobowiązana jest do wydania postanowienia o odrzuceniu odwołania, jeżeli zostało ono oparte na zarzucie niezwrócenia wadium. Na rodzaj wydawanego orzeczenia nie ma wpływu okoliczność, czy wadium zostało zatrzymane przez zamawiającego zgodnie $z$ regulacjami p.z.p.

Obowiązek zwrotu wadium, na etapie postępowania o udzielenie zamówienia publicznego w przypadku wycofania przez wykonawcę oferty przed upływem terminu składania ofert oraz złożenia odpowiedniego wniosku, nie przesądza jednak, że KIO wyda odmienne rozstrzygnięcie. Zgodnie bowiem z art. 189 ust. 1 pkt 2 p.z.p. KIO odrzuca odwołanie, jeśli zostało ono wniesione przez podmiot nieuprawniony. Podmioty uprawnione do korzystania ze środków ochrony prawnej przewidzianych w p.z.p. zostały wymienione w art. 179 ust. 1. Podkreślenia wymaga, że status prawny nie jest jedynym czynnikiem wpływającym na przysługiwanie podmiotowi legitymacji procesowej. Możliwość wniesienia odwołania uzależniona została dodatkowo od dwóch przesłanek: posiadania interesu w uzyskaniu danego zamówienia oraz poniesienia bądź możliwości poniesienia szkody w wyniku naruszenia przez zamawiającego przepisów p.z.p. W omawianym zakresie kluczowe znaczenie ma pierwsza $z$ wymienionych przesłanek. W orzecznictwie powszechnie przyjmuje się, że posiadanie interesu we wniesieniu środków ochrony prawnej związane jest $z$ celem korygującym postępowania odwoławczego i z umożliwieniem odwołującemu uzyskania zamówienia. Zatem interes w uzyskaniu zamówienia należy definiować jako interes obiektywny (rzeczywisty), tj. wynikający z rzeczywistej utraty możliwości uzyskania zamówienia lub ubiegania się o udzielenie zamówienia oraz potrzeby uzyskania określonego rozstrzygnięcia. W świetle aktualnego 
orzecznictwa odwołujący posiada interes, jeżeli wskutek wydania przez KIO wyroku uwzględniającego ma możliwość uzyskania zamówienia.

Nie pozostawia żadnych wątpliwości, że wykonawca, który wycofał swoją ofertę, nie może uzyskać zamówienia, a zatem nie ma interesu prawnego we wniesieniu odwołania, ergo powinno ono zostać odrzucone $\mathrm{w}$ formie postanowienia. W swoich orzeczeniach KIO wskazuje jednak, że stwierdzenie braku legitymacji czynnej do wniesienia środków ochrony prawnej prowadzi do oddalenia odwołania ${ }^{12}$. Powyższe stanowisko podzielają również sądy powszechne. Egzemplifikacyjnie można przywołać orzeczenie Sądu Okręgowego (SO) w Warszawie ${ }^{13}$, w którym stwierdzono, że "artykuł 179 ust. 1 i 2 p.z.p. wskazuje okoliczności uzasadniające poszukiwanie ochrony prawnej w drodze środków odwoławczych. Okoliczności te mają charakter przesłanek materialnoprawnych, czyli przesłanek zasadności wnoszonego środka. Ich zaistnienie nie wpływa na możność wszczęcia procedur odwoławczych, lecz warunkuje uwzględnienie wniesionego środka. Brak uszczerbku $\mathrm{w}$ interesie prawnym wykonawcy w uzyskaniu zamówienia (albo nienaruszenie przez zamawiającego przepisów ustawy) nie oznacza, że postępowanie odwoławcze nie może się rozpocząć, lecz jedynie, że odwołanie wniesione w takich warunkach zostanie oddalone".

Zdaje się, że przywołane stanowisko SO w Warszawie wynika z doświadczenia nabytego w związku z orzekaniem na podstawie regulacji kodeksu postępowania cywilnego ${ }^{14}$. W świetle art. 199 k.p.c. brak legitymacji procesowej prowadzi do oddalenia powództwa, nie zaś do odrzucenia pozwu ${ }^{15}$. Należy jednak zauważyć, że stanowisko takie nie pozostaje $\mathrm{w}$ zgodności $\mathrm{z}$ niebudzącym wątpliwości interpretacyjnych brzmieniem regulacji p.z.p. Powyższego rozumienia regulacji nie przełamuje również odesłanie zawarte w art. 185 ust. 7 p.z.p. do przepisów k.p.c., albowiem obejmuje ono swym zakresem jedynie regulacje o sądzie polubownym, na które ponadto należy się powołać, jedynie gdy p.z.p. nie stanowi inaczej.

12 Wyrok KIO z 13 IX 2011 r., sygn. KIO 1837/11; KIO 1841/11; KIO 1853/11; KIO 1854/11; KIO 1855/11, LEX nr 954980.

13 Wyrok SO w Warszawie z 6 VI 2008 r., sygn. V Ca 1040/08, LEX nr 1713168.

14 Ustawa z dnia 17 XI 1964 r. Kodeks postępowania cywilnego (tekst jedn. Dz.U. 2014, poz. 101 ze zm.), dalej „k.p.c.".

15 Zob. wyrok SN z 6 IV 2004 r., sygn. I CK 628/03, LEX nr 500174; wyrok Sądu Apelacyjnego w Łodzi z 14 XI 2013 r., sygn. I ACa 629/13, LEX nr 1396870. 
Zatem w związku z niebudzącym wątpliwości brzmieniem katalogu okoliczności skutkujących wydaniem przez KIO postanowienia o odrzuceniu odwołania takie orzeczenie powinno być wydane w przypadku braku któregokolwiek z elementów konstruujących legitymację do wniesienia odwołania. Ergo zważając na brak legitymacji procesowej wykonawcy, który wycofał ofertę w dochodzeniu zwrotu wadium przed KIO, tenże organ powinien wydać postanowienie o odrzuceniu odwołania.

\section{Niemożliwość nakazania przez KIO zwrotu wadium}

Pomimo że KIO zobligowana jest do odrzucenia odwołania opartego na zarzucie niezwrócenia przez zamawiającego wadium, warto dodatkowo wskazać argumentację przedstawioną przez SN w postanowieniu z 12 lutego 2014 r. Chociaż SN nie uchwycił w tymże orzeczeniu części kluczowych aspektów, wskazał, że „czynność zatrzymania przez zamawiającego wadium nie ma wpływu na wybór najkorzystniejszej oferty przez zamawiającego, a więc nie wpływa na wynik postępowania w powyższym rozumieniu"16. Przywołany argument odwołuje się do okoliczności wskazanej w art. 192 ust. 2 p.z.p., warunkującej wydanie wyroku uwzględniającego od konsekwencji naruszenia przepisów (verba legis "miało wpływ lub może mieć istotny wpływ na wynik postępowania o udzielenie zamówienia" ${ }^{17}$. Niewątpliwie, zatrzymanie wadium, nawet niezgodne z regulacjami p.z.p., nie wpływa ani nie może wpłynąć na wynik postępowania.

W przytoczonym orzeczeniu SN wskazał również na katalog rozstrzygnięć KIO w przypadku uwzględnienia odwołania (art. 192 ust. 3 p.z.p.). Przepis ten "nie przewiduje możliwości wydania przez KIO rozstrzygnięć odnoszących się bezpośrednio do żądania zasądzenia od zamawiającego na rzecz wykluczonego wykonawcy zatrzymanego wadium, co czyni wątpliwym cel wnoszenia oraz skuteczność odwołań opartych jedynie na argumencie bezpodstawności zatrzymania wadium [... $]^{\prime 18}$.

Podstawowa argumentacja stanowiska SN nie powinna być opierana na przywołanych kwestiach, albowiem KIO, odrzucając odwołanie, nie bada, czy zachodzą przesłanki pozwalające na wydanie wyroku

\footnotetext{
16 Postanowienie SN z 12 II 2014 r., sygn. IV CSK 291/13.

17 Zob. K. Różowicz, Analiza sformułowania "wpływ na wynik postępowania" w prawie zamówień publicznych, cz. III, LEX nr 271269.

18 Postanowienie SN z 12 II 2014 r., sygn. IV CSK 291/13.
} 
uwzględniającego odwołanie, a tym bardziej nie wydaje rozstrzygnięcia zgodnie $z$ art. 192 ust. 2 p.z.p. Jednakże argumenty te pomocniczo, poprzez doprecyzowanie charakteru prawnego postępowania odwoławczego, ukazują, że KIO nie jest organem właściwym do wydawania orzeczeń w sprawach o zwrot wadium, a precyzując, o zapłatę kwoty stanowiącej równowartość wniesionego wadium. Procedura odwoławczo-skargowa uregulowana przepisami p.z.p. nie została przez ustawodawcę ukształtowana w sposób pozwalający na dochodzenie tego rodzaju roszczeń.

\section{Dopuszczalność drogi sądowej zgodnie z regulacjami k.p.c.}

Jak słusznie zauważył SN w postanowieniu z 12 lutego 2014 r., "sprawa o zwrot wadium zatrzymanego przez zamawiającego (a ściślej, o zasądzenie jego wartości) jest sprawą cywilną w sensie materialnoprawnym i formalnym". Na charakter tejże sprawy nie wpływa okoliczność wniesienia wadium $\mathrm{w}$ trakcie postępowania o udzielenie zamówienia publicznego czy też w trakcie innego procesu nabywania towarów i usług. Do rozpoznania spraw o zapłatę kwoty odpowiadającej wysokości wniesionego wadium, jako spraw cywilnych, zgodnie $\mathrm{z}$ art. 2 w zw. z art. 1 k.p.c. właściwe są sądy powszechne.

W glosowanym postanowieniu $\mathrm{SN}$, uznając cywilnoprawny charakter roszczenia, wskazał za sądem II instancji, iż „ judykaturze zgodnie przyjmuje się, że droga sądowa może być niedopuszczalna bezwzględnie, względnie oraz czasowo. Niedopuszczalność drogi sądowej jest uznawana za czasową (przejściową) wtedy, gdy skierowanie sprawy na tę drogę zostało mocą przepisu szczególnego uzależnione od wyczerpania postępowania przed innym organem, co oznacza, że wcześniejsze wytoczenie sprawy przed sąd prowadzi do odrzucenia pozwu albo do przekazania jej właściwemu organowi. W ocenie Sądu Apelacyjnego, z taką sytuacją mamy do czynienia w niniejszej sprawie, na co wskazuje brzmienie art. 179 i n. [...] Dopiero po rozstrzygnięciu sporu przed KIO strona niezadowolona z treści wydanego rozstrzygnięcia może wnieść skargę do właściwego sądu okręgowego. Taka sytuacja określana jest mianem przejściowej niedopuszczalności drogi sądowej".

Czasowa niedopuszczalność drogi sądowej wymaga uprzedniego wyczerpania trybu postępowania przed innym organem. Przykładami uregulowań prawnych przewidujących osobną procedurę, której wyczerpanie stanowi warunek dopuszczający wystąpienie na drogę 
postępowania sądowego, są: ustawa o gospodarce nieruchomościami ${ }^{19}$ (art. 79 i 80), Prawo telekomunikacyjne ${ }^{20}$ (art. 107), Prawo geologiczne i górnicze ${ }^{21}$ (art. 151) czy Prawo ochrony środowiska (art. 131) ${ }^{22}$. Wszystkie wymienione regulacje w sposób wyraźny warunkują możliwość wystąpienia na drogę postępowania sądowego uprzednim wyczerpaniem drogi postępowania administracyjnego albo reklamacyjnego. Czasowej niedopuszczalności drogi sądowej nie można bowiem domniemywać. Regulacje procesowe ustaw szczególnych muszą w tym zakresie zawierać wyraźne postanowienia (zob. art. $2 \S 3$ k.p.c.).

Nie sposób zgodzić się ze stanowiskiem, że art. 179 p.z.p. lub jakikolwiek inny przepis powszechnie obowiązujący taką regulację przewiduje. W p.z.p. unormowana jest szczegółowa procedura kontrolna o charakterze hybrydowym, sprawowana przez KIO w ramach postępowania odwoławczego oraz przez sądy powszechne w ramach postępowania skargowego ${ }^{23}$. Procedura odwoławczo-skargowa ma swoisty charakter wynikający z celu jej ukształtowania. Zadaniem kontroli przeprowadzanej w wyniku skorzystania ze środków ochrony prawnej nie jest wyciągnięcie konsekwencji względem zamawiającego naruszającego prawo, lecz skorygowanie jego działań i czynności tak, aby udzielić zamówienia publicznego podmiotowi wybranemu w sposób zgodny z przepisami p.z.p. O korygującym charakterze postępowania świadczy m.in. art. 181 ust. 1 p.z.p., zgodnie z którym wykonawca lub uczestnik konkursu może poinformować zamawiającego o niezgodnej z przepisami ustawy czynności podjętej przez niego lub zaniechaniu czynności, do której jest on zobowiązany na podstawie ustawy, na które nie przysługuje odwołanie. Nadto należy wskazać na możliwość samokontroli zamawiającego zarówno przed wydaniem orzeczenia przez $\mathrm{KIO}$, jak i po nim ${ }^{24}$, która to samokontrola wyeliminuje konieczność korygowania jego działań przez $\mathrm{KIO}^{25}$.

19 Ustawa z dnia 21 VIII 1997 r. o gospodarce nieruchomościami (tekst jedn. Dz.U. 2015, poz. 1773 ze zm.).

20 Ustawa z dnia 16 VII 2004 r. Prawo telekomunikacyjne (tekst jedn. Dz.U. 2014, poz. 243 ze zm.).

${ }^{21}$ Ustawa z dnia 9 VI 2011 r. Prawo geologiczne i górnicze (tekst jedn. Dz.U. 2015, poz. 196 ze zm.).

${ }^{22}$ Ustawa z dnia 27 III 2001 r. Prawo ochrony środowiska (tekst jedn. Dz.U. 2013, poz. 1232 ze zm.).

23 Zob. K. Różowicz, Charakterystyka..., s. 137-155.

${ }^{24}$ K. Różowicz, Uprawnienia zamawiajacego do samokontroli, „Monitor Zamówień Publicznych" 2015, nr 8(132), s. 23-25.

25 Wyrok KIO z 19 XI 2012 r., sygn. KIO 2441/12, LEX nr 1237673; wyrok KIO z 13 IV 2011 r., sygn. KIO 707/11, LEX nr 788988. 
W glosowanym orzeczeniu błędnie zatem zidentyfikowano sui generis hybrydową procedurę odwoławczą jako konstrukcję tzw. tymczasowej niedopuszczalności drogi sądowej, co skutkowało przyjęciem, że droga ta jest ograniczona koniecznością orzekania w I instancji przez KIO w każdej ze spraw jakkolwiek związanych z procesem udzielania zamówień.

\section{Ocena zasadności zatrzymania wadium dokonana przez sąd powszechny}

Sąd Najwyższy w glosowanym orzeczeniu czasową niedopuszczalność drogi sądowej wywodzi również z niemożliwości zastąpienia KIO przez sąd powszechny w procesie wykładni przesłanek uzasadniających zatrzymanie przez zamawiającego wadium (art. 46 ust. 4a p.z.p.). Zdaniem sądu "byłoby to zastępowanie orzeczenia specjalnie do tego powołanego organu przez ten sąd".

W przywołanym stanowisku po raz wtóry przyjęto, że wszelkie sprawy wynikłe ze stosunku łączącego zamawiającego z wykonawcą poddane są kognicji KIO. Należy zgodzić się ze wskazanym w orzeczeniu stanowiskiem o wyspecjalizowanym charakterze KIO, zdaje się jednak, że niedostatecznie precyzyjnie dostrzeżono zakres tego ukierunkowania. Kognicja KIO nie obejmuje bowiem wszystkich spraw związanych $\mathrm{z}$ udzielaniem zamówień albo powstałych $\mathrm{w}$ związku z procesem nabywania dóbr i usług przez zamawiających. Jak zostało już wskazane, przedmiotem odwołania mogą być wyłącznie czynności lub zaniechania zamawiającego mające miejsce $\mathrm{w}$ trakcie postępowania o udzielenie zamówienia publicznego.

Ponadto istnienie w strukturach publicznych wyspecjalizowanego organu orzeczniczego $\mathrm{w}$ sporach powstałych $\mathrm{w}$ związku $\mathrm{z}$ zachowaniem zamawiającego na etapie postępowania o udzielenie zamówienia nie skutkuje niemożliwością podejmowania procesu wykładni przepisów regulujących tę przestrzeń życia społecznego przez inne podmioty, w tym przez sądy powszechne. Każdorazowo sąd powszechny, rozpoznając sprawę o zapłatę równowartości wniesionego wadium, zobowiązany jest do ustalenia stanu faktycznego sprawy, w tym do oceny zgodności z prawem zatrzymania przez zamawiającego wadium i wydania na tejże podstawie orzeczenia. 


\section{Podsumowanie}

Postanowienie Sądu Najwyższego z 27 listopada 2014 r. ukazuje trudności interpretacyjne wynikające ze złożoności materii prawa zamówień publicznych. SN, orzekając o niedopuszczalności dochodzenia roszczenia o zasądzenie wartości zatrzymanego wadium, błędnie ocenił charakter ukształtowanego przez ustawodawcę hybrydowego postępowania skargowo-odwoławczego, czego konsekwencją było przyjęcie, że wszelkie sprawy jakkolwiek związane z procesem udzielenia zamówienia należą w I instancji do kognicji KIO.

Stanowisko takie nie może zostać podzielone, m.in. w świetle ukazanych w glosie konsekwencji procesowych oparcia odwołania na zarzucie niezwrócenia wadium (odrzucenie odwołania albo oddalenie odwołania). W świetle obowiązujących przepisów KIO nie ma kompetencji do orzekania w sprawie zatrzymania wadium oraz zasądzenie jego wartości na rzecz wykonawcy.

Nie powinno budzić wątpliwości interpretacyjnych, że w ramach postępowania odwoławczego nie jest możliwe dochodzenie tychże roszczeń. Ich dochodzenie jest możliwe wyłącznie przed sądem powszechnym, na drodze postępowania regulowanego w warstwie proceduralnej przepisami k.p.c. Zatem nawet jeżeli wykonawca skorzystał ze środków ochrony prawnej, zasądzenie zwrotu wadium nie może nastąpić w ramach procedury odwoławczo-skargowej przewidzianej w p.z.p.

Uzupełniająco należy wskazać, że KIO nie będzie organem właściwym do rozpoznania również innych roszczeń przysługujących wykonawcom, np. o zwrot próbek ${ }^{26}$ czy o zwrot uzasadnionych kosztów uczestnictwa w postępowaniu. Spory te, niewątpliwie o charakterze cywilnoprawnym, wyłączone są spod kognicji KIO ze względu na ich niekompatybilność z przyjętym modelem postępowania odwoławczego.

26 K. Różowicz, Próbki po przetargu, „Przetargi Publiczne” 2015, nr 11, s. 29-32. 